\title{
Affective Factors in Second Language Acquisition and Its Application to Foreign Language Teaching
}

\author{
LI Xiao-yan \\ Wuhan Institute of Technology, 430205, Wuhan
}

\begin{abstract}
There are many factors influencing learner's foreign language ability. With the basic principles of psycholinguistics, the author mainly analyses the affective factors in second language acquisition and put forward some suggestions for developing the positive role of the affective factors so as to increase the efficiency of foreign language teaching and develop students' ability to use a foreign language.
\end{abstract}

Keywords-affective factors; second language acquisition; application; foreign language teaching

\section{INTRODUCTION}

Psycholinguistics focuses on a large quantity of issues including perception, comprehension, production, acquisition of language, as well as the relationship between language and emotions or personalities. One needs knowledge about phonetics, phonology, morphology, syntax, semantics and pragmatics so as to use language, during the process of which learner's emotions, memories and thinking are also concerned. In this sense, psycholinguistics provides foreign language teaching with scientific theories and methods. People usually consider foreign language teaching a matter of teaching method, while according to psycholinguistics, many variables are involved during the process of foreign language teaching. There are many factors influencing foreign language teaching, among which are native language transfer, cognitive style, metacognition, affective or personality factors, cultural factors, learning environment, learning styles, learning strategies, language input and output, communication competence, age, gender, language aptitude, etc. It's extremely difficulty or even impossible to take all the above-mentioned elements into consideration. The solution lies in put emphasis on some certain aspects and pay less attention to the rest. The following is focused on affective factors in second language acquisition and its application to foreign language teaching.

\section{AFFECTIVE FACTORS IN SECOND LANGUAGE ACQUISITION}

Affect means emotion or feeling. As to the definition of affective domain, different scholars both at home and abroad have their own opinions. Among all the definitions, the one given by Benjamin Bloom and his colleagues is widely accepted so far. According to them, affective domain includes such factors as self-esteem, inhibition, anxiety, risktaking, empathy and extroversion.

\section{A. Different kinds of affective factors}

Self-esteem is a person's self-evaluation. It indicates an individual believes in himself and has confidence in his abilities. According to Brown, there are three kinds of selfesteem:general self-esteem which is a person's general idea about himself and considered to be unchanging unless some therapy has been taken, specific self-esteem which refers to one's own self-evaluation in some specific situations or when dealing with specific tasks, task self-esteem which is related to specific tasks in specific situations. Inhibition is a feeling of shyness of embarrassment that stops one doing or saying what he really want. As one of affective factors, inhibition is close related to self-esteem. As is known to all, it's inevitable to make mistakes when students express their ideas in oral English class. If teachers frequently and strictly point out students' mistakes, students with big ego are active and optimistic to face and correct their mistakes, and they can make progress by learning from mistakes. While those with weak sense of self-esteem may think it's a shame to be criticized in front of such a large audience, therefore,they would build a wall of inhibition to protect what is selfperceived to be a weak ego, which, undoubtedly, will inhibit them from speaking English in class. Anxiety is a complicated state of emotion which includes such feelings as nervousness, worry, self-doubt or fear. Horwitz believes anxiety may fall into three kinds: communication apprehension which will appear when people can't express their ideas when communicating with target language, fear of negative social evaluation which will appear when people are afraid of losing face in learning language, and test anxiety which will appear when people are confronted with test. Risk-taking means when learning a foreign language, learners are willing to take the risk of making mistakes. People with high self-esteem are not afraid of being laughed at when being wrong, while people with smaller ego are less likely to take risks. Empathy means the willingness and ability to understand and share other's ideas or feelings. Hogan identifies two elements of empathy: one being the knowledge of one's own feelings, and the other being identification with another person. Extroversion is another important factor in second language learning. Extroverted students are active, talkative, outgoing and sociable, and are considered to get more opportunities to practice English, thus they are more likely to do better in the development of communicative competence. 


\section{B. Correlation of affective factors}

All the above mentioned affective factors are closely related to each other.As Krashen points, affective factors play a great role in second language acquisition, and just like Filter, they decide how much language input can be taken in by language learners and eventually transfer to be language competence. Failure in foreign language acquisition can more or less result from different kinds of affective disorders. In the process of learning English, students with high selfesteem are quite confident about their capacities, thus they have full confidence in developing their abilities to use English comprehensively, which will lead them to take effective measures to learn English actively. If students don't have a strong sense of ego and their foundation of English is very poor, it is possible that when learning English they may experience inferiority, timidity, nervousness, worry or even fear, all of which will undoubtedly play a negative role in their language learning.

Take pronunciation for example. As is known to all, pronunciation just takes up a small part of foreign language learning, yet whether or not people learn pronunciation well in the preliminary stage of learning plays a significant role in the subsequent language learning. With standard pronunciation, the student may get praise from the teacher and become the envy of his fellow students when answering a question in class, which will bring forth the appearance of sense of pride, add to his motivation of learning and improve learning efficiency. From this point of view, learning pronunciation well can contribute to language learning. On the other hand, if a student has terrible pronunciation, when expressing his ideas in public, he may be misunderstood because of his poor pronunciation.Worse still, his weakness is revealed in front of the whole class, which may make his classmates laugh at him and give a bad impression on the teacher as well. If so, the student may build a wall of inhibition by instinct because being laughed at by others makes him lose face and damages his self-esteem. When being asked to answer a question next time, he may feel anxious, or instead of speaking, he simply keeps silence in case of being mocked at. In this case, the student may refuse to learn English, which leads to the end of language input. Such series of psychological reactions caused by awful pronunciation may result in decline of motivation and meanwhile undermine learner's confidence, forming the vicious circle. From the above analysis, one can see it clearly that affective factors have an enormous influence on second language acquisition.

\section{Application of affective factors in foreign language teaching}

Since affective factors play such a great role in second language acquisition, teachers can make full use of them and apply them to foreign language teaching from the following two aspects.

\section{CREATE A RELAXED CLASS ATMOSPHERE}

A relaxing class atmosphere can relieve student's pressure and stimulate their interest in language learning as well.
When being asked to stand up and answer questions, some students may feel very nervous, with their voice trembling, not knowing where to put their hands. They are too nervous to get their ideas across. In order to handle this, instead of asking students to stand up or go to the front of classroom, the teacher may ask them to answer questions with just sitting on chairs. If possible, students can sit in circle to carry out group discussion. These measures can shorten the students-teacher distance as well as the distance between students themselves. It's an effective way to eliminate students' mental burden and help them adopt a carefree attitude to foreign language learning.

Next, the teacher may use some humorous languages. For example, students are required to set their mobile phones to silence when learning in class. Still there's someone who either forgets to do it or turns a blind eye to the rule. When the teacher is analyzing something difficult and important, loud music bursts out from someone's mobile phone. The analysis definitely has to be interrupted. Under this circumstance, if the teacher harshly criticizes the student, it will have a negative effect on all people's mood without doubt. The teacher can handle it in other ways. He may say: thanks for sharing your favorite song with us, but would you please choose something better next time? These words enable the student to realize he's done something wrong, without exerting pressure on him. It can be seen obviously that humorous language makes the tense atmosphere relaxed. Meanwhile, the teacher should offer substantial help to those students in need. For example, when talking about different recreational activities, some students can just come up with some words instead of sentences because of their poor foundation of English, but still they're eager to take part in class discussion. In this case, the teacher may offer some sentence patterns for reference. Students with a good command of English need not refer to those sentence patterns, while to those with poor foundation of English, these sentence patterns are very helpful to them, with which they can take part in discussion without feeling worried or anxious.

\section{GIVE POSITIVE AFFECTIVE FEEDBACKS ON STUDENTS' MISTAKES}

As an old Chinese saying goes, to err is human. It is true of students in the process of language learning. It's inevitable that every student may make mistakes either in English listening, speaking, reading, writing or translating. What the teacher is supposed to bear in mind is that he should give positive affective feedbacks on students' mistake no matter what personalities the students have or whether or not the students have a good command of English. The point is that the teacher should treat their mistakes in different ways.

According to Bailey, the teacher may choose to treat students' mistakes immediately or later, and he may also choose to ignore their mistakes. If an extroverted student with high self-esteem makes a mistake in class, he is likely to expect the mistake to be corrected, because this time he knows the reason for the mistake and the correct answer, he would avoid making the same mistake next time. On this occasion, the teacher may first say something like "OK, I 
like it very much" and then point out the mistake and correct it immediately. If a lower-ego student makes a mistake in class, that the teacher points out the mistake in front of other students will let him lose face and hurt him, which may lead the student to inhibit himself from participating in class discussion. Therefore, if so, the teacher may respond to him by saying "That's very interesting, I love it", and then he may point out and correct the student's mistake in private during the break or after class. In this way, the student gets positive feedback and meanwhile get his mistake corrected.

\section{CONCLUSIONS}

Learning a foreign language is a long and complex process, which requires both students and teachers to make great efforts. In addition to the above two suggestions, teachers should do something more, for example, respect and trust students, spend time and energy communicating with students, treat students as friends, take an active part in students' extracurricular activities, etc. in order to relieve students' anxiety and motivate them. Only in this way, can the efficiency of foreign language teaching be increased and students' ability to use a foreign language be developed.

\section{References}

[1] Bailey, K.M. Classroom-centered Research on Language Teaching and Learning. In Celce-Murcia (Ed.). Beyond Basics: Issues and Research in TESOL, 96-121. Rowley, MA: Newbury House, 1985.

[2] Brown, H.D. Principles of Language Learning and Teaching[M]. Beijing: Foreign Language Teaching and Research Press, 2002.

[3] GUI Shi-chun. Psycholinguistics (New Edition)[M]. Shanghai:Shanghai Foreign Language Education Press, 2000.

[4] Hogan, Robert. Development of an Empathy Scale[J]. Journal of Consulting and Clinical Psychology, 1969, 33: 307-316.

[5] Horwitz, E.K., Horwitz, M.B., and Cope, J. Foreign Language Classroom Anxiety[J]. Modern Language Journal, 1986, 70: 125-132.

[6] Krashen, S. The Input Hypothesis[M]. London: Longman, 1985.

[7] Krathwohl, David R., Bloom, Benjamin, and Masia Bertram.B. Taxonomy of Educational Objectives. Handbook H: Affective Domain[M]. New York: David McKay Company, 1964.

[8] YAN Chuan-hai \& ZHANG Mei-juan. Effects of Affective Factors in EFL Classroom[J]. Foreign Language World, 2002(5): 64-66. 